\title{
ESTIMATE OF GLACIER ABLATION UNDER A DEBRIS LAYER FROM SURFACE TEMPERATURE AND METEOROLOGICAL VARIABLES
}

\author{
By M. NAKAWO* \\ (Geotechnical Section, Division of Building Research, National Research Council of Canada, \\ Ottawa, Ontario K1A 0R6, Canada) \\ and G. J. YounG \\ (Snow and Ice Division, National Hydrology Research Institute, Inland Waters Directorate, \\ Environment Canada, Ottawa, Ontario K1A 0E7, Canada)
}

\begin{abstract}
A simple model suggests that the ablation under a debris layer could be estimated from meteorological variables if the surface temperature data of the layer are available. This method was tested by analyzing the data obtained from experiments with artificial debris layers. Fairly good agreement was obtained between the estimated and the experimental data.

RÉSUMÉ. Evaluation de l'ablation d'un glacier sous une couche détritique à partir de la température de surface et de variables metéorologiques. Il est possible, grâce à un modèle simple, d'évaluer l'ablation d'un glacier sous une couche de roches détritiques en fonction de variables météorologiques si l'on possède des données sur la température de surface de la couche détritique. Ce modèle a èté vérifiè lors de l'analyse des données provenant d'essais effectués au moyen de couches détritiques artificielles. Les données expérimentales sont venues corroborer les données obtenues à l'aide des modèles théoriques.
\end{abstract}

ZuSAMmENFASSUNG. Abschätzung der Eisablation unter einer Schuttschicht mit Hilfe der Oberflächentemperatur und von meteorologischen Daten. Aus einem einfachen Modell geht hervor, dass die Ablation unter einer Schuttschicht aus meteorologischen Daten abgeschätzt werden kann, wenn die Oberflächentemperatur der Schicht bekannt ist. Diese Methode wurde mit Hilfe von Daten erprobt, die aus Versuchen mit künstlichen Schuttschichten hervorgingen. Zwischen den abgeschätzten und den experimentell gewonnenen Werten ergab sich eine recht gute Übereinstimmung.

\section{INTRODUCTION}

In order to evaluate glacier ablation under a debris layer, Nakawo and Young (1981) proposed a simple model which was successfully employed in analyzing experimental data. With this model, ablation under a debris layer can be estimated from meteorological variables when the thermal resistance of the layer is known. Since it is difficult to determine directly the thermal resistance of a layer of unknown material in the field, it was suggested that the surface temperature of the debris layer may be used for estimating the thermal resistance and consequently the ablation under the layer.

This paper presents the results of testing the validity of the proposed method by comparing estimated data with field measurements. The symbols used are defined in Table I.

\section{MODEL}

The energy-balance equation at a debris surface, in which all the terms are taken to be positive downward, is given by

$$
C=F+H+E
$$

where

$$
F=(1-\alpha) G+A-\sigma\left(T_{\mathrm{s}}+273 \mathrm{~K}\right)^{4},
$$
\footnotetext{
060 .

* Present address: Department of Applied Physics, Faculty of Engineering, Hokkaido University, Sapporo, Japan
} 


$$
\begin{gathered}
H=\beta u_{\mathrm{a}}\left(T_{\mathrm{a}}-T_{\mathrm{s}}\right), \\
E=\beta L_{\mathrm{e}} u_{\mathrm{a}} \frac{0.623}{p c_{p}}\left(e_{\mathrm{a}}-e_{\mathrm{s}}\right) .
\end{gathered}
$$

Assuming a steady temperature profile in the debris layer (i.e. a linear profile for a uniform layer), then

$$
C=\frac{T_{\mathrm{s}}}{R}
$$

since the temperature at the ice-debris interface is $0^{\circ} \mathrm{C}$ and $T_{\mathrm{s}}$ is in degrees Celsius. Neglecting the variation of the stored heat in the layer, and assuming no conduction of heat into the ice beneath, then

$$
C=L_{\mathrm{f}} \rho_{\mathrm{i}} r .
$$

When condensation takes place, it is assumed that $e_{\mathrm{s}}$ is equal to the saturation vapour pressure, which is a function of $T_{\mathrm{s}}$. As long as the debris surface is wet, this assumption is also made for periods when evaporation occurs. For a dry surface, on the other hand, $e_{\mathrm{s}}$ is assumed to be equal to $e_{\mathrm{a}}$.

By combining Equations (1) through (6) and eliminating $T_{\mathrm{s}}$ (and $e_{\mathrm{s}}$ with the above assumptions), one can estimate $r$ for a given $R$ when $F$ (or $G$ and $A$ if $\alpha$ is known), $u_{\mathrm{a}}, T_{\mathrm{a}}, p$, and $e_{\mathrm{a}}$ are provided. This was demonstrated by Nakawo and Young (1981). In most cases in the field, however, the value of $R$ is unknown.

When $T_{\mathrm{s}}$ is given instead, $F, H$, and $E$ can be estimated (Equations (2) through (4)), allowing $R$ to be determined by combining Equations (1) and (5). Once $R$ is determined, $r$ can be estimated for other periods using the procedure mentioned above. This is the method to be tested.

\section{EXPERIMENTAL DATA}

Experiments were carried out at Peyto Glacier (lat. $51^{\circ} 41^{\prime}$ N., long. $116^{\circ} 33^{\prime}$ W.) in the Rocky Mountains, Alberta, Canada from 20 to 22 August 1979. Meteorological variables

\section{TABLE I. NOMENCLATURE}

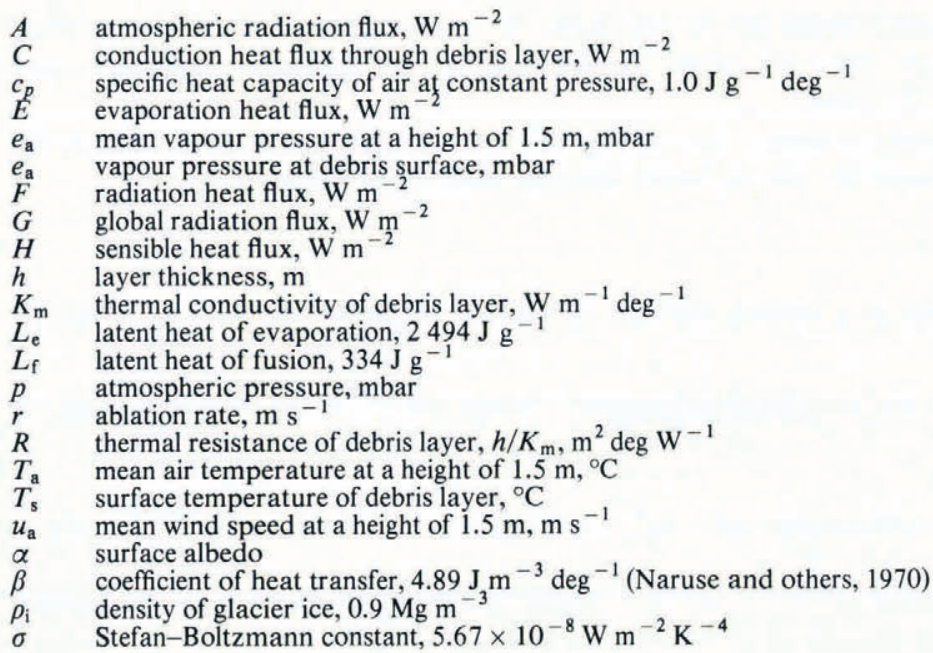


during the measurement period are summarized in Table II. The data were collected using the procedures reported by Nakawo and Young (1981).

The ablation rate under debris layers was observed at six plots prepared artificially with debris materials collected from the supraglacial debris of the glacier. Each plot was $0.3 \mathrm{~m}$ square with a layer thickness $h$ given in Table III. The ablation at the plots during a given period was determined by measuring the increase in the relative distance between the debris surface and a taut string installed over the plots. The results are also compiled in Table III.

Surface temperature was measured by a thermistor inserted within a few millimetres of the surface of the debris. This measurement was made only twice in the daytime, but this is considered to be satisfactory for a test of the method as the weather was very stable during the experiments (e.g. atmospheric pressure was almost constant at $803.1 \pm 1$ mbar). The observed values for $T_{\mathrm{s}}$ of the measurements are shown in Table IV.

\section{TEST RESULTS AND DISCUSSION}

The albedo of the layers was not determined. The debris material had a relatively dark colour and its albedo, when dry, was considered to be about 0.1 to 0.2 (Penndorf, 1956; Geiger, 1961). For a wet surface, the albedo decreases by about $20 \%$ (Geiger, 1961), but it was still considered to be in the range of 0.1 to 0.2 .

By substituting the values of $T_{\mathrm{s}}$ (Table III) and meteorological variables (Table IV) into Equations (2) through (5), and combining with Equation (1), $R$ was estimated for each plot. The estimated values are shown in Table III. Uncertainty in $R$ was caused both by the uncertainty in the albedo and by the difference in the two estimates for 21 and 22 August. It should be noted that $E$ in Equations (1) and (4) was assumed to be zero in the calculation for plot $\mathrm{F}$ because its surface was dry. Thermal conductivity $K_{\mathrm{m}}$ estimated from these $R$ values was in the range 1.4 to $2.6 \mathrm{~W} \mathrm{~m}^{-1} \mathrm{deg}^{-1} \mathrm{~m}$ (Table III) which are comparable with the values obtained for various soils (e.g. Kersten, 1949; Penner and others, 1975; Jumikis, 1977).

The ablation rate was calculated using the data on meteorological variables given in Table II, and assuming $\alpha=0.1$ and $\alpha=0.2$. The results are plotted against $R$ in Figure 1 (a) for the first two periods and (b) for the latter two periods. The solid and dashed lines are for wet and dry surfaces respectively in the daytime. The short dashed lines correspond to the estimates for night-time. The observed ablation rates in Table III are also plotted in Figure 1 using the $R$ values given in Table III.

The agreement between calculation and observation is fairly good, although there are some discrepancies. It is considered that the disagreement could be attributed to uncertainty in the estimates of $R$ because there were few measurements of $T_{s}$, and there was the uncertainty as to whether the temperature was in a steady state at the time of the observations. The errors involved in the measurement of $T_{\mathrm{s}}$ could also cause an error in the determination of $R$,

TABLE II. METEOROLOGICAL VARIABleS DURING THE EXPERIMENTAL PERIOD

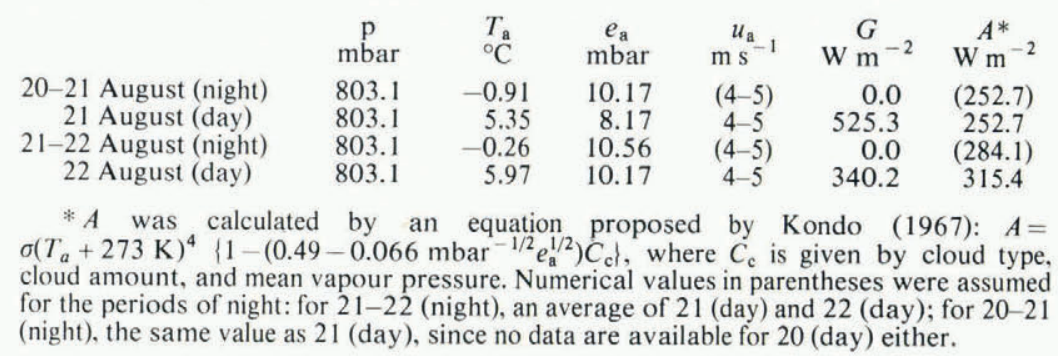




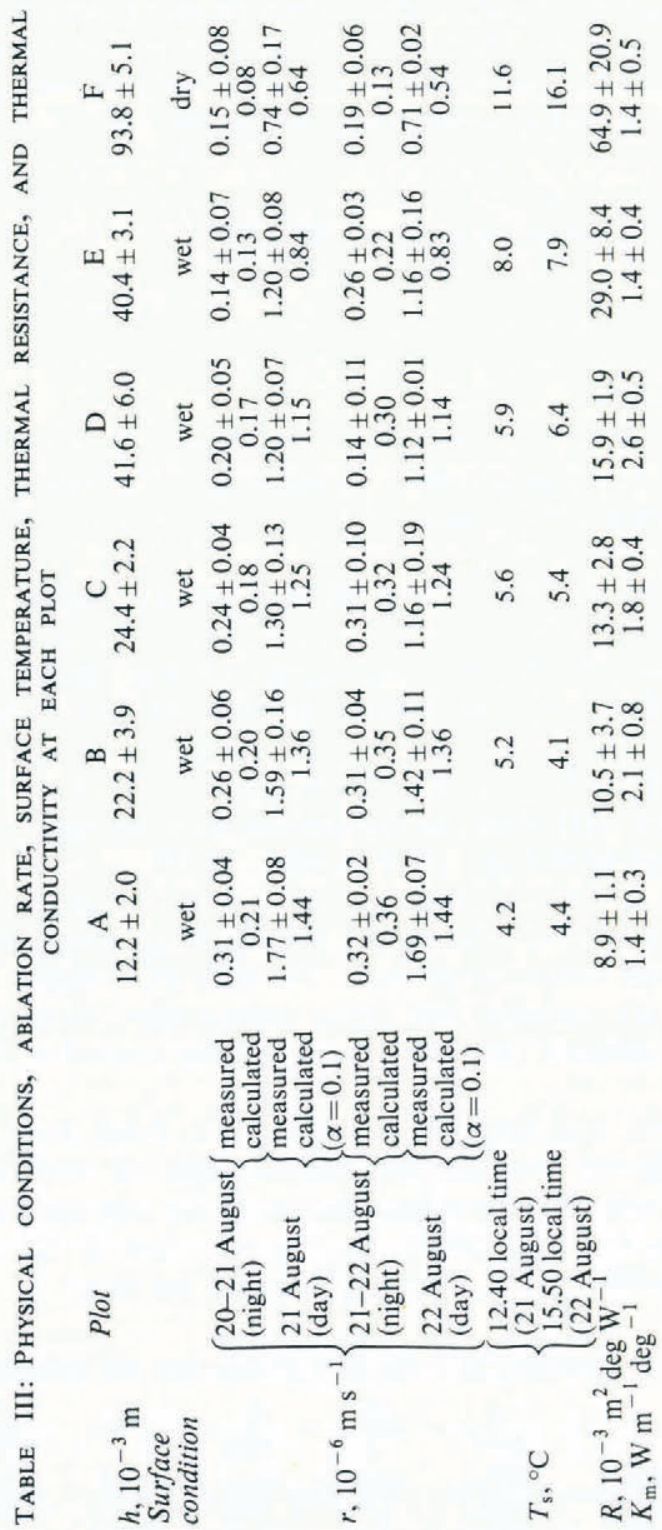


TABLE IV. VALUES FOR THE METEOROLOGICAL VARIABLES WHEN THE SURFACE TEMPERATURE WAS MEASURED

12.10-13.10 local time (21 August)

15.20-16.20 local time (22 August)

$$
\begin{gathered}
p \\
\text { mbar }
\end{gathered}
$$

803.1

803.1

\section{$T_{\mathrm{a}}$
${ }^{\circ} \mathrm{C}$}

6.16

11.83

$u_{\mathrm{a}}$
$\mathrm{m} \mathrm{s}^{-1}$
$4-5$
$4-5$

w $\stackrel{G}{m}$

W m

567.0

441.0
$\mathrm{W} \mathrm{m}^{*}$

252.7

* $A$ was assumed to be the mean value for the daytime, as its variation is small within a day.

particularly when $R$ is large. For plots $\mathrm{E}$ and $\mathrm{F}$, for example, a 0.5 deg difference in $T_{\mathrm{s}}$ would result in $10 \times 10^{-3}$ and $5 \times 10^{-3} \mathrm{deg} \mathrm{W}^{-1}$ difference respectively in the value of $R$ when the modified $T_{\mathrm{s}}$ is applied through Equations (1) to (5).

Another source of disagreement between the calculated and the observed data is the uncertainty in the value of $\beta$. The value of $4.89 \mathrm{~J} \mathrm{~m}^{-3} \mathrm{deg}^{-1}$ is an average compiled by Naruse and others (1970) from the data for $\beta$ obtained at various surfaces of glaciers, snow fields, and artificial basins. The original data for $\beta$ scattered in a range of $\pm 1.16 \mathrm{~J} \mathrm{~m}^{-3} \mathrm{deg}^{-1}$ around the mean value. Owing to the presence of the experimental plots, the surface roughness of these plots on Peyto Glacier was greater than that of a natural glacier surface. This would result in a larger value of $\beta$ than for a natural surface. The value of $\beta$ at the plot could therefore have been larger than $4.89 \mathrm{~J} \mathrm{~m}^{-3} \mathrm{deg}^{-1}$. Using a larger value of $\beta$ would result in a larger ablation rate for a given $R$; if $R$ is large, however, an increase in the value of $\beta$ has little effect. The value of $\beta$ is also dependent on wind stratification. Log-linear profiles of wind speed and temperature were found applicable at the glacier (Derikx, [1975]; Munro and Davies, 1977, 1978). In the present experiments advection could have played an important role in heat exchange at the surfaces of the plots, since the area of the plots was small. However, the determination of the value of $\beta$ taking the advection term into consideration is a very complex problem.

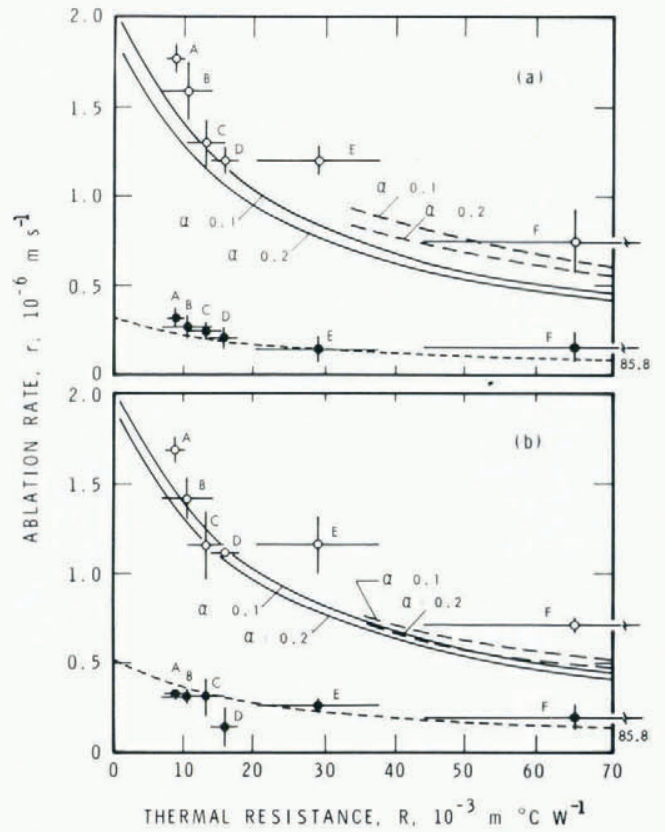

Fig. I. Ablation rate versus thermal resistance during 20-21 August (a) and 21-22 August (b). Solid and open circles are observed data during nighttime and daytime respectively. Short dashed lines show the estimation from meteorological variables for night-time. Solid and dashed lines represent the calculation for wet and dry surface respectively during daytime. 
Nonetheless, the general agreement between the calculated and observed values suggests that glacier ablation under a debris layer can be predicted from meteorological and surface temperature measurements. To obtain a good prediction, it is recommended, as pointed out by Kraus ([1975]), that special attention be paid to surface roughness which is sometimes very large at stagnant areas near termini of glaciers (see e.g. Iwata and others, 1980). A continuous record of surface temperature as well as observations on temperature profile in the debris layer would also improve the prediction.

\section{ACKNOWLEDGEMENTS}

The authors would like to thank $\mathrm{N}$. Maeno and $\mathrm{H}$. Narita of the Institute of Low Temperature Science, Hokkaido University, for their assistance in the field, and L. W. Gold of the Division of Building Research, National Research Council of Canada, for encouraging them to write this paper.

MS. received 19 December 1980 and in revised form 5 May 1981

\section{REFERENCES}

Derikx, A. L. [1975.] The heat balance and associated runoff from an experimental site on a glacier tongue. IUnion Géodésique et Géophysique Internationale. Association Internationale des Sciences Hydrologiques. Commission des Neiges et Glaces.] Symposium. Neiges et glaces. Actes du colloque de Moscow, août 1971, p. 59-69. (IAHS-AISH Publication No. 104.)

Geiger, R. 1961. Das Klima der bodennahen Luftschicht. Vierte Auflage. Braunschweig, Friedrich Vieweg und Sohn. [English translation: The climate near the ground. Translated by Scripta Technica, Inc. Cambridge, Mass., Harvard University Press, 1965.]

Iwata, S., and others. 1980. Surface morphology in the ablation area of the Khumbu Glacier, |by| S. Iwata, O. Watanabe, and H. Fushimi. Seppyō, Vol. 41, Special Issue, p. 9-17.

Jumikis, A. R. 1977. Thermal geotechnics. New Brunswick, N.J., Rutgers University Press.

Kersten, M. S. 1949. Thermal properties of soils. Bulletin of the University of Minnesota Engineering Experiment Station, No. 28.

Kondo, J. 1967. Analysis of solar radiation and downward long-wave radiation data in Japan. Scientific Report of Tohoku University, Ser. 5, Vol. 18, No. 3, p. 91-124.

Kraus, H. [1975.] An energy balance model for ablation in mountainous areas. IUnion Géodesique et Geophysique Internationale. Association Internationale des Sciences Hydrologiques. Commission de Neiges et Glaces.| Symposium. Neiges et glaces. Actes du colloque de Moscow, août 1971, p. 74-82. (IAHS-AISH Publication No. 104.)

Munro, D. S., and Davies, J. A. 1977. An experimental study of the glacier boundary layer over melting ice. Journal of Glaciology, Vol. 18 , No. 80 , p. 425-36.

Munro, D. S., and Davies, J. A. 1978. On fitting the log-linear model to wind speed and temperature profiles over a melting glacier. Boundary-Layer Meteorology, Vol. 15, No. 4, p. 423-37.

Nakawo, M., and Young, G. J. 1981. Field experiments to determine the effect of a debris layer on ablation of glacier ice. Annals of Glaciology, Vol. 2, p. 85-91.

Naruse, R., and others. 1970. Kion-yūsetsu no yagai kenkyū [Field studies on snow melt due to sensible heat transfer from the atmosphere]. [By] R. Naruse, H. Öura, [and] K. Kojima. Teion-kagaku: Low Temperature Science, Ser. A. [No.] 28, p. 191-202.

Penndorf, R. 1956. Luminous reflectance (visual albedo) of natural objects. Bulletin of the American Meteorological Society, Vol. 37, No. 4, p. 142-44.

Penner, E., and others. 1975. Thermal conductivity laboratory studies of some Mackenzie Highway soils, by E. Penner, G. H. Johnston, and L. E. Goodrich. Canadian Geotechnical Journal, Vol. 12, No. 3, p. $271-88$. 